\title{
SEXUAL ORIENTATION DISCRIMINATION \\ - A EUROPEAN PERSPECTIVE THROUGH THE PRACTICE OF THE COURT OF JUSTICE OF THE EUROPEAN UNION AND OF THE CONSTITUTIONAL COURT OF THE REPUBLIC OF CROATIA
}

\author{
Marina Čepo, PhD candidate, Teaching and Research Assistant \\ Josip Juraj Strossmayer University of Osijek, \\ Academy of Arts and culture Osijek \\ Kralja Petra Svačića 1/f, Osijek, Croatia \\ mcepo@uaos.hr
}

\section{Ana-Marija Kovačević, student}

Josip Juraj Strossmayer University of Osijek, Academy of Arts and culture Osijek

Kralja Petra Svačića 1/f, Osijek, Croatia

ana.marija.kovacevic7@gmail.com

\section{Martina Lučić, student}

Josip Juraj Strossmayer University of Osijek,

Academy of Arts and culture Osijek

Kralja Petra Svačića 1/f, Osijek, Croatia

martina.lucic.os@gmail.com

\section{ABSTRACT}

Any discrimination or exclusion based on sexual orientation for the purpose of reducing equality before the law, as well as providing preferential treatment on these grounds, constitutes sexual orientation discrimination. This paper will, inter alia, address the rights of same-sex partners vis-à-vis the rights of heterosexual partners, with the aim of analyzing the current stage of the European perspective in the area where the legal arrangements of certain EU Member States 
(hereinafter: MS) will be presented by a comparative method. It is precisely these issues that have been decided by the Court of Justice of the European Union (hereinafter: CJEU), from which the major problems in the area of sexual orientation discrimination are identified. In the view of the CJEU, in order for a treatment to be characterized as discrimination on the basis of sexual orientation, a community of same-sex partners must be legalized in a MS. Only when such a legal framework exists can the CJEU decide whether there is a basis for discrimination. Such an interpretation begs the question, what about states that do not have any legal framework that recognizes the same-sex life community? The first part of the paper will analyze international and European standards of protection against sexual orientation discrimination, and after that, the current level of same-sex rights in the EU will be briefly presented. The second part of the paper will be based on analysis of the impact of CJEU decisions on changes in Romanian legislation in the field of recognizing the effect of same-sex marriage, concluded in another MS, as well as an analysis of the process of recognizing the effect of same-sex marriage in the Republic of Croatia (hereinafter: Croatia) In addition, the paper will also analyze the judgment of the Constitutional Court of the Republic of Croatia (hereinafter: CCRC) regarding discrimination on the grounds of sexual orientation observed in the positive regulation governing the issue of foster care. Based on these analyzes, de lege ferenda guidelines will be given at the end of the paper in order to reduce the possibility of sexual orientation discrimination.

Keywords: sexual orientation discrimination, CJEU, equality, same-sex partners

\section{INTRODUCTION}

This paper discusses sexual orientation discrimination and the rights of same-sex communities in the European Union (hereinafter: the EU). The prohibition of discrimination, which also applies to sexual orientation discrimination, has its foundations in international and EU law. During the last quarter of the 20th century, it can be clearly seen that attitudes towards same-sex communities still vary greatly between nations, but as legal decriminalization gradually progresses and it moves towards increasing recognition and equality of same-sex communities, however, not in all MS. The integration and coexistence of same-sex communities within one nation is most commonly manifested at the legal level, such as the right to a partnership or marriage. The analysis of EU countries shows that there are still major differences in the approach to regulating same-sex partnership. Some countries recognize same-sex marriage and have the necessary legal regulations to make same-sex marriage equal to traditional marriage. In other countries, however, there is another type of institution that is not called marriage but most often a registered partnership. Currently, the biggest problem in the EU are MS that do not recognize any form of same-sex community. In such countries, like Romania, same-sex partners remain without legal protection. EU promotes the rights of same-sex communities, but each MS adopts its own legislation on same-sex partnerships. A society committed to equality and non-discrimination portrays the development of an awareness of individuality and acceptance of the diversity and equality of all persons before the law, which should be an aspiration for every society. The first 
part of the paper will analyze international and European standards of protection against sexual orientation discrimination, and after that, the current level of samesex rights in the EU will be briefly presented. The second part of this paper will analyze the impact of CJEU decisions, as a binding and important source of law in EU, on changes in Romanian legislation in the field of recognizing the effect of same-sex marriage, concluded in another MS, as well as an analysis of the process of recognizing the effect of same-sex marriage in the Croatian system. In the light of the analysis of sexual orientation discrimination in Croatia, an analysis of the judgment of the CCRC will be made, related to the observed discriminatory provision of the legislation governing foster care. Based on these analyzes, de lege ferenda guidelines will be given at the end of the paper in order to reduce the possibility of sexual orientation discrimination.

\section{PROHIBITION OF SEXUAL ORIENTATION DISCRIMINATION IN INTERNATIONAL LAW AND LAW OF THE EUROPEAN UNION}

When defining homosexuality, Borić considers it's a physical, sexual, emotional and spiritual attraction to a person of the same sex. ${ }^{1}$ Sexual orientation discrimination or gender identity means any distinction, exclusion or preferential treatment on these grounds, which aims at the annulment or reduction of equality before the law, that is, the recognition, enjoyment or enjoyment on an equal basis of all human rights and fundamental freedoms. ${ }^{2}$

\subsection{INTERNATIONAL LAW}

When it comes to International human rights law, the Universal Declaration of Human Rights imposes as a milestone which proclaims, by Article 2, equality and prohibits discrimination:

"Everyone is entitled to all the rights and freedoms set forth in this Declaration, without distinction of any kind, such as race, colour, sex, language, religion, political or other opinion, national or social origin, property, birth or other status. "3

\footnotetext{
1 Borić, R., Pojmovnik rodne terminologije prema standardima Europske unije, Ured za ravnopravnost spolova Vlade RH, Centar za ženske studije, Biblioteka ONA, Zagreb, 2007, p. 30

2 Yogyakarta Principles - Principles on the application of international human rights law in relation to sexual orientation and gender identity, International Commission of Jurists (ICJ), 2007, Available at: [https://www.refworld.org/docid/48244e602.html], accessed 01. April 2020

3 Universal Declaration of Human Rights, 10 December 1948., 217 A (III)
} 
As the provisions of the Universal Declaration of Human Rights are not legally binding on States, or have no binding force, its provisions have been transposed into the International Covenant on Civil and Political Rights, ${ }^{4}$ and in the International Covenant on Economic, Social and Cultural Rights, ${ }^{5}$ to make these provisions the obligations of all MS. The International Covenant on Civil and Political Rights, in Article 2 (1) states that each State Party undertakes to respect and guarantee the rights recognized by the Covenant to all persons within its territory and territories within its jurisdiction, regardless of race, color skin, gender, language, religion, political or other belief, national or social origin, property, birth or other circumstance. The International Covenant on Economic, Social and Cultural Rights in Article 2 (2) states in much the same way that States Parties undertake to guarantee that the rights set out in the Covenant will be exercised without any discrimination regarding race, color, sex, language, religion, political or other belief, national or social origin, property, birth or any other circumstance. Therefore, the term "sexual orientation" as a basis for discrimination is not mentioned in the Universal Declaration of Human Rights or in the two international pacts subsequently adopted. Nonetheless, States Parties are obliged to protect persons against sexual orientation discrimination, since, in the opinion of the UN Human Rights Committee and the Committee on Economic, Social and Cultural Rights, sexual orientation is an integral part of the protected sex/gender base, resulting from the Article 2 of the Covenant on Civil and Political Rights, and as such falls into the category of expressly cited grounds under Article 26 of the same Covenant. ${ }^{6}$ Therefore, it is clear that the prohibition of discrimination does not only relate to the grounds mentioned above, but this prohibition is much broader and requires equality of every person before the law. The role of States Parties is significant because, as stated by the UN Committee on Human Rights, the principle of equality sometimes requires States to take certain positive steps to alleviate or abolish conditions that lead to, or may lead to discrimination. ${ }^{7}$

4 International Covenant on Civil and Political Rights, 16 December 1966, TS 999, p. 171, The Republic of Croatia is a party to the International Covenant on Civil and Political Rights of 6 October 1991, pursuant to the Decision on the publication of multilateral international treaties to which the Republic of Croatia is a party on the basis of succession notifications. The decision was taken by the Government of the Republic of Croatia on 30 September 1993 (Official Gazette - International Agreements, No. 12/1993)

5 International Covenant on Economic, Social and Cultural Rights, 16 December 1966, TS 993, p. 3

6 This principle is confirmed in the case Toonen v. Austria, No. 488/1992, United Nations, 1994. In cases Young v. Australia, Communication No. 941/2000, United Nations, 2003 and Xv. Colombia, No.1361 / 2005, United Nations, 2007, such principle was reaffirmed.

7 General Comment No. 18 of the Human Rights Committee, United Nations, 1989, para. 10, Available at: [http://www.bgcentar.org.rs/bgcentar/wp-content/uploads/2013/04/Op\%C5\%A1ti-comments-Community-for-Human-Rights.pdf], accessed 10. April 2020 
Article 14 of the European Convention for the Protection of Human Rights and Fundamental Freedoms (hereinafter: ECHR) guarantees equal access to all human rights and fundamental freedoms, set out in the Convention, for all persons:

"The enjoyment of the rights and freedoms recognized in this Convention shall be ensured without discrimination on any grounds, such as gender, race, color, language, religion, political or other opinion, national or social origin, national minority, property., Birth or other circumstances. "8

ECHR has limited reach, as it guarantees rights and freedoms only on the grounds mentioned above, but Protocol no. 12. takes a step further and proclaims a general prohibition of discrimination. ${ }^{9}$ It is clear that neither ECHR nor Protocol 12. do not mention the prohibition of discrimination on grounds of sexual orientation. However, the European Court of Human Rights (hereinafter: ECtHR) has played a major role in deciding that Article 14 of the ECHR covers sexual orientation, and the explanatory report to Protocol no. 12 indicates that this instrument would provide protection against sexual orientation discrimination. ${ }^{10}$ The ECtHR considers that, within the meaning of Article 14 of the ECHR, different treatment is discriminatory as there is no reasonable and objective justification for it, respectively if it does not seek to achieve a legitimate aim. ${ }^{11}$ The ECtHR also considers that the margin of appreciation afforded to states in such cases, that interferes with one of the most intimate matters of private life, is narrow and that there must be particularly serious reasons that would justify interference by public authorities. ${ }^{12}$ The role of the States Parties to the ECHR and Protocol no. 12. was reaffirmed as essential, but the ECtHR made it clear that there must be a proportionality between the means used and the aim to be achieved, as the necessity of achieving that goal must be proved. The ECtHR also played a major role in strengthening the rights of same-sex communities by interpreting certain provisions of the ECHR, so it follows from the case-law of the ECtHR that the relationship of homosexual marriage can indeed be encompassed by the terms "private" and "family life" on the same basis as heterosexual marriage in a comparative situation. ${ }^{13}$ As

8 European Convention for the Protection of Human Rights and Fundamental Freedoms, as amended by Protocols Nos. 11 and 14, 4 November 1950, ETS 5

9 Protocol 12 to the European Convention on Human Rights and Fundamental Freedoms on the Prohibition of Discrimination, 4 November 2000, ETS 177

10 See: Judgment Salgueiro da Silva Mouta v. Portugal (1999) 31 EHRR 1055, as well as: Judgment Karner v. Austria (2003) 38 EHRR 528

11 Judgment Karner v. Austria, ibid., para. 37

12 Ibid., para. 41

13 According to: Judgment Vallianatos and others v. Greece (2013) 59 EHRR 12, para. 73, as well as Judgment Orlandi and others v. Italy (2017) 389 ECHR 1153, para. 143 
Joseph and Castan point out, it should be borne in mind that the States Parties do not have complete freedom in defining the family, as this would significantly weaken the guarantees under Art. 23 of the International Covenant on Civil and Political Rights. Thus, a State Parties would not be able to adopt the definition of the family by applying values that are in complete conflict with the standards of international human rights protection. ${ }^{14}$ The disadvantage in this interpretation is that no criteria have been set in International human rights law, according to which it would be decided what would be contrary to fundamental human rights and freedoms, ie whether the restriction of family and marriage to the community of men and women is considered as violation of these rights.

\subsection{EUROPEAN UNION LAW}

When it comes to EU law, it is important to emphasize that European human rights law has evolved in line with the normative progress of human rights protection at the UN and Council of Europe levels. Unlike the international organizations that created the first human rights instruments, sexual orientation discrimination is already mentioned at European level in the Treaty of Amsterdam. ${ }^{15}$ Relevant provisions of the Treaty on European Union (hereinafter: TEU) and the Treaty on the Functioning of the European Union (hereinafter: TFEU) refer, as explicitly stated, on the prohibition of sexual orientation discrimination and gender identity. ${ }^{16}$ This means that the TEU and TFEU include sexual orientation on the list of grounds for discrimination. Likewise, the Charter of Fundamental Rights of the European Union (hereinafter: the EU Charter) in Article 21 (1) contains a general anti-discrimination provision, which explicitly states sexual orientation as a basis for discrimination:

"Any discrimination based on any ground such as sex, race, colour, ethnic or social origin, genetic features, language, religion or belief, political or any other opinion, membership of a national minority, property, birth, disability, age or sexual orientation shall be prohibited."

14 Joseph, S.; Castan, M., The International Covenant on Civil and Political, Rights: Cases, Materials and Commentary, 3rd edition, Oxford: Oxford University Press, 2013, p. 668

15 Treaty of Amsterdam Amending the Treaty on European Union, The Treaties Establishing the European Communities and Related Acts [1997] SL C 340, Article 6 (a): "Without prejudice to the other provisions of this Treaty and within the limits of the powers conferred by it upon the Community, the Council, acting unanimously on a proposal from the Commission and after consulting the European Parliament, may take appropriate action to combat discrimination based on sex, racial or ethnic origin, religion or belief, disability, age or sexual orientation"

16 Consolidated version of the Treaty on the Functioning of the European Union [2007] SL C 326

17 Charter of Fundamental Rights of the European Union [2012] SL C 326 
Article 9 of the EU Charter stipulates that the right to marriage and family life must be ensured at national level. Given that there is no mention of the phrase "man and woman" in the said provision, Barić and Vincan consider that at European level there is no barrier to recognition of same-sex relationships in the context of marriage, but there is also no explicit requirement that MS should allow same-sex marriage. ${ }^{18}$ European Council Directive 2003/86/EC on the right to family reunification ${ }^{19}$ explicitly states sexual orientation as a basis for discrimination, as does Directive 2000/78/EC establishing a general framework for equal treatment in employment and occupation, stating that the purpose of the directive is to establish a general framework for combating against discrimination on the grounds of religious belief, disability, age or sexual orientation in relation to employment and occupation, in order to ensure that the principles of equal treatment are applied in the MS (hereinafter: Directive 2000/78) ${ }^{20}$ Directive 2000/78 applies to all persons, whether in the public or private sector, including public institutions. The prohibition of discriminatory conduct applies equally to nationals of EU MS, as well as third country residing in the EU. ${ }^{21}$ Petrašević, Duić and Buljan state that the purpose of any legal order is to give individuals in their social community the full and free development of their personality, including sexual orientation as well. However, as they state, the legislation of individual MS on same-sex community are regulated in different ways, as this aspect of status law falls under the exclusive competence of MS. ${ }^{22}$ In 2016, the Council of the EU adopted a Regulation 2016/1103 implementing enhanced cooperation in the area of jurisdiction, applicable law and the recognition and nforcement of decisions in matters of matrimonial property regimes (hereinafter: Regulation 2016/1103),

18 Barić, S.; Vincan, S., Ustavnopravno načelo jednakosti i pravno uređenje istospolnih zajednica, Zbornik radova Pravnog fakulteta u Splitu, vol. 50, no. 1, 2013, p. 103

19 Council Directive 2003/86/EC on the Right to Family Reunification [2003] OJ L 251

20 Council Directive 2000/78/EC establishing a general framework for equal treatment in employment and occupation [2000] OJ L 303, Article 1

21 Ibid., According to Article 2 there are four types of discrimination: direct discrimination, indirect discrimination, harassment, and instruction to discriminate. Direct discrimination presupposes that a particular person is treated worse than another in similar situations. Indirect discrimination is when a seemingly neutral provision puts the measure or conduct in an unequal position of a person of a particular sexual orientation compared to other persons, except when those provisions of the measure or conduct are justified by a legitimate aim and the means to achieve it are appropriate and necessary. Humiliation is a form of discrimination that results in undesirable behaviors related to sexual orientation in order to violate a person's dignity and to create an intimidating, hostile and degrading or abusive environment. An instruction to discriminate against persons on any grounds shall be deemed to be discrimination

22 Petrašević, T.; Duić, D.; Buljan, E., Prava istospolnih zajednica u Europskoj uniji s posebnim osvrtom na Republiku Hrvatsku, Strani Pravni život, vol. 61, no. 3, 2017, p. 167 
which inter alia regulates the issue of property rights in registered partnership. ${ }^{23}$ The provisions in the aforementioned text clearly distinguish between married and registered communities from unregistered partnerships. The regulation respects the basic principles of the EU Charter, such as the principle of non-discrimination and respect of family and private life. Despite the Regulation 2016/1103 and its regulation, there are differences in the legislation of the MS on property matters. The CJEU has played a major role in the formation of European legal regulation regarding the rights of same-sex communities, as well as the protection against discrimination on grounds of sexual orientation, which will be discussed later in this paper.

\section{THE RIGHTS OF SAME SEX COMMUNITIES IN THE NATIONAL LEGISLATION OF THE MEMBER STATES}

An analysis of the legislations of the MS shows that there are still major differences in the regulation of same-sex partnerships as well as the application of European law. Some countries (eg. Netherlands, Spain, Portugal, France, Germany, Finland, Norway) recognize same-sex marriage in their legislation and have the necessary legal regulations to make same-sex marriage more equitable to traditional marriage. ${ }^{24}$ In other countries (eg. Italy, Croatia, Slovenia, Hungary and the Czech Republic) there is another type of community not called marriage but a registered partnership. ${ }^{25}$ There are also countries that do not recognize any form of same-sex community (eg. Bulgaria, Latvia, Lithuania, Poland, Romania, Slovakia). ${ }^{26}$ As Petrašević, Duić and Buljan point out, the fact that each EU country defines its own legislation on same-sex partnership raises the issue of resolving legal situations if the partners are from countries that differently define same-sex partnership. ${ }^{27}$ Currently, the biggest problem are countries that do not recognize any form of same-sex partnership. In such countries, same-sex marriage partners, who are legally married, are not entitled to the rights arising from such status, which can lead to many legal issues and violations of the fundamental rights to which they are entitled. The Netherlands is the first country ever to legalize same-sex marriage

23 Council Regulation (EU) 2016/1103 implementing enhanced cooperation in the area of jurisdiction, applicable law and the recognition and nforcement of decisions in matters of matrimonial property regimes [2016] SL L 183

24 Lipka, M.; Masci, D., Where Europe stands for gay marriage and civil unions, Pew Research Center, 2019, Available at: [https://www.pewresearch.org/fact-tank/2019/10/28/where-europe-stands-on-gaymarriage-and-civil-unions], accessed 10. April 2020

25 Ibid.

26 Ibid.

27 Petrašević; Duić; Buljan, op. cit., note 22, p.148 
back in $2001 .^{28}$ By legalizing same-sex marriage, they equated it with traditional marriage before the law and allowed same-sex partners to adopt children. For this reason, among others, the Netherlands is a country that can be taken as an example when it comes to equality and non-discrimination of persons on the basis of sexual orientation. It is interesting to note that Denmark legalized the first formal form of same-sex community in 1989, that produced all the rights and obligations produced by marriage. ${ }^{29}$ The Czech Republic does not allow same-sex marriage, but it permits another type of non-marriage community. ${ }^{30}$ In 2006, the Czech Republic legalized a registered partnership, as a formal life-form of persons of the same sex, thereby becoming, according to Jagielska, the first country of the former Eastern Bloc to recognize and legalize some form of same-sex community. ${ }^{31}$ Such legislation exists also in Croatia, Italy and Hungary. On the basis of a referendum held in 2013, Croatia introduced the provision in the Constitution of the Republic of Croatia (hereinafter: Constitution Act) that states: "marriage is a community of a woman and a man." ${ }^{32}$ Croatia institutionalized the same-sex community by Same-Sex Communities $\mathrm{Act}^{33}$ that was adopted in 2003, which was in force until 2014, when the Life Partnership of Persons of the Same Sex Act was adopted. ${ }^{34}$ Croatia differentiates formal from an informal life partnership that equates with an extramarital community. ${ }^{35}$ Italy stated in its legal provisions that all same sex communities of Italian nationals concluded abroad would be recognized, as if they were assembled under Italian law, and provides registered partnership for samesex partners. ${ }^{36}$ Such legislation is a consequence of the ECtHR decision in Oliari and Others $v$ Italy case, when the ECtHR ruled that Italy had breached Article 8 of the ECHR guaranteeing the right to privacy and family life by lack of legal recognition of same-sex relationships. ${ }^{37}$ Hungary also knows only the form of a

\footnotetext{
28 Dutch Civil Code [1992] NLD-1992-L-91671, Article 1:30.

29 The Danish Registered Partnership Act [1989] D/341- H- ML, Act No. 372

30 Chech Civil Code [2012] 89/2012 Sb.

31 See: Jagielska, M., Eastern European Countries: From Penalisation to Cohabitation or Further?, in: Boele-Woelki, K.; Fuchs, A. (es.) Legal Recognition of Same-Sex Relationships in Europe, National, CrossBorder and European Perspectives,Cambridge Portland, 2012

32 Constitution of the Republic of Croatia, consolidated text, Official Gazette No. 56/90, 135/97, 08/98, $113 / 00,124 / 00,28 / 01,41 / 01,55 / 01,76 / 10,85 / 10,05 / 14$, Article 62

33 Same-Sex Communities Act, Official Gazette, No. 116/2003

34 Life Partnership of Persons of the Same Sex Act, Official Gazette, No. 92/14, 98/19

35 Ibid., Article 3

36 Italian Act on civil partnerships between persons of the same sex, and on living together without being married, Official Gezette, No. 76

37 Judgment Oliari and Others v Italy (2015) Application no. 18766/11 and 36030/11
} 
registered partnership without providing right to same-sex marriage. ${ }^{38}$ As stated by Szeibert-Erdős, ${ }^{39}$ in 1999 and 2002, the Hungarian Constitutional Court made very important decisions equalizing the required age for consent in a heterosexual and homosexual community, which resulted with change in the legal and social perception of homosexuality in Hungary ${ }^{40}$ Romania is among the most recent states in Europe to decriminalize homosexuality. Although same-sex community rights, activists have advocated repealing Article 200 of Romania's Criminal Code since the early 1990s, its removal was only accepted in June 2001 when Romania began EU accession negotiations as an indicator of progress in aligning its laws with EU legislation. ${ }^{41}$ Ireland is the first country to legalize same-sex marriage on the basis of a referendum in 2015, when the people of Ireland decided in favor of same-sex marriage, giving same-sex partners the right to be legally equated to traditional marriage. ${ }^{42}$ Such a referendum presents opportunities for other countries that have legal restrictions on equalizing same-sex partnership rights with traditional marriage rights. There are six such countries in the EU: Bulgaria, Latvia, Lithuania, Poland, Romania and Slovakia. Such a solution may encourage other countries to launch a referendum if public opinion and laws in the country do not match. Romania, Bulgaria, Lithuania and Latvia are EU countries where the opinion of society is not on the side of same-sex marriage and there is no regulation on same-sex partnership in these countries. ${ }^{43}$ That confirms that Western countries are more prone to non-discrimination, while in eastern EU countries, with a few exceptions, public opinion is still conservative.

\section{DISCRIMINATION ON THE BASIS OF SEXUAL ORIENTATION THROUGH THE PRACTICE OF CJEU}

The first case in which the CJEU found sexual orientation discrimination was Tadao Maruko v Versorgungsanstalt der deutschen Bühnen case (hereinafter: Maruko

38 Hungarian Civil Code, [1960] Act VI

39 Szeibert-Erdős, O., Same-sex partners in Hungary - Cohabitation and registered partnerships, Utrecht Law Review, Igitur, vol. 4, no. 2, 2008, p. 215

40 Decisions of the Hungarian Constitutional Court, No. 20/1999 (VI. 25.), ABH, 1999, p. 159. and No. 37/2002 (IX. 4.), ABH, 2002, p. 230

41 Andreescu V., From Legal Tolerance to Social Acceptance: Predictors of Heterosexism in Romania, Revista Romana de Sociologie, vol 3-4, 2011, p. 209-231

42 Ireland Marriage Act [2015] No. 35, previously Bill No. 78

43 Pew Research Center, Eastern and Western Europeans Differ on Importance of Religion, Views of Minorities, and Key Social Issues, 2018, Available at: [https://fra.europa.eu/en/databases/anti-muslim-hatred/ node/4277], accessed 11. April 2020 
case). ${ }^{44}$ In that case, thr CJEU ruled that MS are obliged to treat equally couples who are in heterosexual marriage and those in a registered same-sex community in a comparable situation. What the CJEU has left to the national courts is to decide on a case-by-case basis whether this is indeed a comparable situation. At the time of the judgment in the Maruko case, such a judgment seemed to have moved far beyond the boundaries of same-sex rights. Such a view is understandable, given that by that time the CJEU had taken completely different decisions in this area, and thus, such a judgment was revolutionary. The CJEU brought clear guidance to MS to guarantee equal rights to same-sex partners as to persons in heterosexual marriage in a comparative situation, but left them to determine what those situations were. Furthermore, it did not push the boundaries when it comes to states that do not recognize any form of same-sex community, and in the Maruko case made it clear that discrimination on the basis of sexual orientation can only be addressed if a particular MS knows some form of same-sex community in its legislation, otherwise, there is no comparative situation in which such discrimination against the homosexual community could be reflected. The fact that certain states in the 21 st century do not recognize any form of same-sex community in their legislation is, if not legal, then certainly morally discriminatory. According to Krešić, another weaknesses of the Maruko ruling is that the EU still believes that defining marital status should remain entirely within the competence of the MS. ${ }^{45}$ Unlike in the case above, in the case of Frédéric Hay $v$ Crédit agricole mutuel de Charente-Maritime et des Deux-Sèvres, the CJEU itself examines whether or not marriage partners are in a comparable situation to persons having a registered partnership because of their inability to marry in a particular MS. ${ }^{46}$ The CJEU has held that married persons and registered partnerships are in a comparable situation and that, therefore, the reduction of workers' rights, such as days off and bonuses due to marriage, is a direct discrimination based on sexual orientation. The latest decision in which the Court ruled on discrimination on the basis of sexual orientation and, accordingly, advance the rights of same-sex communities by protecting primarily the right to freedom of movement and its effects in the Member States, was the case of Relu Adrian Coman, Robert Clabourn Hamilton and Asociatia Accept $v$ Inspectoratul General. to the Immigrant Center (hereinafter: Coman case), which

44 See more: Case C-267/06 Tadao Maruko v Versorgungsanstalt der deutschen Bühnen [2008] ECLI 2008:179

45 Krešić, B., Zajednice života istog spola u pravu zemalja EU, Sarajevski otvoreni centar, Sarajevo, 2015., p. 36-37

46 See more: Case C-267/12 Frédéric Hay v Crédit agricole mutuel de Charente-Maritime et des Deux-Sèvres [2013] ECLI 2013:823 
will be briefly analyzed in the following text. ${ }^{47} \mathrm{~A}$ request for a preliminary ruling was sent to the CJEU as a result of a dispute between Relo Adrian Coman, Robert Clabour Hamilton and the Accept Association and the General Inspectorate of Immigration and the Ministry of the Interior in Romania. Dispute was related to a request by R.C.Hamilton for granting a residence permit for more than three months in Romania. The request therefore concerned the interpretation of the relevant provisions of Directive 2004/38 on the right of citizens of the Union and their family members to move and reside freely within the territory of the MS. ${ }^{48}$ This case was a mirror of what the doctrine warned could happen when persons in the same-sex community wish to move from one MS to another, and thereby exercise the right of free movement, which is one of the cornerstones of the EU.49 In this case, the CJEU reminded the MS that they were obliged to respect the fundamental rights of the EU and in all those areas left to the jurisdiction of the MS. The CJEU also reminded that MS cannot arbitrarily invoke reasons of public interest and national security when accessing restrictions on fundamental rights, such as the right of EU citizens to freedom of movement and the legal effects that right. The CJEU has made it clear that under Directive 2004/38 "spouse" is a gender-neutral term that comes under the term "family member", and a right to reside with a third-country national, who has legally married in one of the EU countries, the MS derives from the provisions of the TFEU. That statement requires recognition of the effects of same-sex marriage concluded in one of the MS, without prejudice to the national position on the existence of same-sex marriage or a registered partnership. With this judgment, the CJEU partially addressed the problem that existed after the Maruko ruling, which was related to those MS that did not know any form of same-sex community in their legislation. Therefore, after the judgment in Coman case all MS, including those who do not know any form of same-sex community in their legislation, are obliged to recognize same-sex marriages concluded in another MS, only in the purpose of exercising the rights conferred on them by EU law. One of the disadvantage of such a judgment is the fact that there is no mention of same-sex marriages that have taken place outside the borders of the EU, when it comes to the EU citizens. What Tryfonidou sees as another drawback is certainly that the verdict deals with cross-border situations,

47 Case C-673/16, Relu Adrian Coman, Robert Clabourn Hamilton and Asociatia Accept v Inspectoratul General pentru Imigrări, Ministerul Afacerilor Interne [2018] SL C 268 (Case C-673/16 Coman)

48 Directive 2004/38/EC of the European Parliament and of the Council on the right of citizens of the Union and their family members to move and reside freely within the territory of the Member States amending Regulation (EEC) No 1612/68 and repealing Directives 64/221/EEC, 68/360/EEC, 72/194/EEC, 73/148/EEC, 75/34/EEC, 75/35/EEC, 90/364/EEC, 90/365/EEC and 93/96/EEC [2004] SL L 158

49 See: Petrašević; Duić,; Buljan, op. cit., note 22, p. 165 
which leaves same-sex partners in domestic, purely national issues still unprotected. ${ }^{50}$ Therefore, the CJEU should express its position more confidently, regardless of the reaction of MS that do not recognize any rights to same-sex communities and leave no room for doubt in the interpretation of its judgments. This would ensure legal certainty and protection of fundamental human rights and freedoms, regardless of the status issues of persons and the legislation of EU MS in which they reside. Such inequality of the legal systems of the MS leads to a situation where same-sex partners move to countries where they will enjoy greater rights and equality, which can lead to forum shopping.

\subsection{IMPACT OF THE JUDGMENT IN THE COMAN CASE ON CHANGES IN ROMANIAN LEGISLATION IN THE FIELD OF RECOGNIZING THE EFFECT OF SAME-SEX MARRIAGE, CONCLUDED IN ANOTHER MEMBER STATE}

In Romania, marriage is defined as a union of man and woman, and in such a marriage citizens have the right to marry in order to start a family. ${ }^{51}$ Same-sex marriage is prohibited, and marriages and registered partnerships made by same-sex partners in another country were not recognized in Romania by Romanian nationals or foreigners at the time of the Coman case, as well as at the time of completion of the analysis for the purposes of this paper. ${ }^{52}$ Romania, following its ruling in the Coman case, declined to amend the text of Article 277 (2) of the Civil Code, according to Hagean, on the grounds that the issue of legalizing same-sex marriage and the recognition of such marriages were left to MS and that, with the appearance of such a decision of the CJEU, the Romanian legislation on these issues cannot be considered repealed or amended. ${ }^{53}$ Furthermore, Romanian's doctrine states that in the judgment the CJEU stated that the marital status of persons, including rules pertaining to marriage, is an issue that falls within the competence of the MS, and that EU law does not affect that jurisdiction, so they are therefore free to provide or not provide same-sex marriage in their own country. It also states that the judgment calls into a question constitutional provisions and does not oblige the Romanian state to legalize same-sex marriage. ${ }^{54}$ Therefore, on the basis

\footnotetext{
50 Tryfonidou1, A., The EU Top Court Rules that Married Same Sex Couples Can Move Freely Between EU Member States as "Spouses": Case C 673/16, Relu Adrian Coman, Robert Clabourn Hamilton, Asociatia Accept v Inspectoratul General pentru Imigrări, Feminist Legal Studies, vol. 27, 2019, p. 211-221

51 Romania Code Civil, Officially Law No. 287/2009, Article 259, para. (1) (2)

52 Ibid., Article 277, para (1) (2)

53 Hageanu, C., Articolul 277 din Codul civil român, încotro?, Revista Româană de Drept Privat, vol. 3 , 2018, p. 151

$54 \quad$ Ibid.p. 152
} 
of such an interpretation, Article 277 of the Romanian Civil Code remained unchanged after the Coman case, with the exception of paragraph 3, which Romania amended following the ECtHR judgment in Oliari and Others $v$ Italy. Romania, misinterpreting a judgment of the Court and not changing its legal provisions explicitly, stating that the effects of same-sex marriage contracted abroad are not recognized, violates international law, EU law and ignores judicial practice that is a source of EU law. Undoubtedly, this judgment promoted the rights of samesex communities, but the merits of this judgment are not the issues of national arrangements for same-sex marriage and registered partnerships, but merely the recognition of such marriages for the purpose of a derived right of residence in a MS on the basis of European law. The consequences of this are enormous. It is unacceptable to prevent nationals of a particular country from exercising their fundamental rights guaranteed by International human rights law and European legislation deriving from the TFEU and from the EU Charter, because of national legislation. Romania, however, has some achievements in terms of equality of person of different sexual orientations. Equality and non-discrimination were achieved at the level of employment, goods and services, education, health and sexual orientation, and the Criminal Code introduced provisions on hate crime based on sexual orientation. ${ }^{55}$ Despite advances in Romanian law, same-sex marriage or some form of same-sex partnership is still not regulated by law.

\subsection{RECOGNITION OF THE SAME-SEX MARRIAGES, CONCLUDED IN ANOTHER MEMBER STATE, IN THE PRACTICE OF REPUBLIC OF CROATIA}

Formal and informal life partnership in Croatia is regulated by the Life Partnership of Persons of the Same Sex Act. Croatian legislation does not recognize the concept of same-sex marriage, but knows the concept of life partnership of persons of the same sex. When a life partnership is concluded in Croatia, the existence of such a partnership is entered in the Life Partnership Register kept by the Ministry of Administration. Such registration is not performed when Croatian citizens enter into a same-sex marriage or life partnership abroad. In that case, according to the data obtained from the Registry Office, on the basis of the Instructions for keeping the Life Partnership Register, ${ }^{56}$ the existence of such a status is entered in the Registry of Birth Certificates kept at the Registry Office according to place of residence. Since Croatian legislation does not recognize the concept of same-sex marriage, a note on the conclusion of a life partnership of

\footnotetext{
55 Romanian Criminal Justice Act [2003] Official Gezette, No. 34, 378, 39, 42

56 Instruction for keeping Life Partnership Register, Official Gazette no. 147/2014, Article 13
} 
persons of the same sex is entered in the Registry of Birth Certificates. ${ }^{57}$ Same-sex marriage is the highest level of realization of the rights of same-sex partners, which would mean that if recognition of the effect of a same-sex marriage contracted abroad is sought, there is a certain degradation of such relationships to the level of life partnership. However, in Croatia, the rights of persons living in a formal or informal life partnership are equal to the rights of extramarital or marital unions. As Lucić points out, regardless of which of the four family law institutes known to Croatian legislative (marriage, cohabitation, formal or informal life partnership) the partners decide to live, they will enjoy exactly the same legal effects. In other words, after three years of living together informal life partners and extramarital partners in Croatian legislative have all the rights and duties as spouses and formal life partners. ${ }^{58}$ Precisely for this reason, a life partnership between persons of the same sex has the same legal effects as a marriage of persons of the opposite sex. In addition, according to the Life Partnership of Persons of the Same Sex Act, life partners who are in a same-sex marriage, or life partnership, have the right to apply for temporary residence as a family member in Croatia. ${ }^{59}$ In addition, persons who are in a same-sex marriage or life partnership and are both EU citizens or at least one of them is an EU citizen "enjoy equal access to rights and benefits that fall within the scope of the guarantee of fundamental freedom of movement within the European Economic Area". ${ }^{60}$ It can therefore be concluded that Croatia fully implements the recognition of the effect of same-sex marriages or life partnerships concluded abroad, provides them with freedom of movement and temporary residence as a family member, in accordance with the decision of the CJEU in the Coman case.

\section{SEXUAL ORIENTATION DISCRIMINATION THROUGH THE PRACTICE OF THE CONSTITUTIONAL COURT OF THE REPUBLIC OF CROATIA}

Although the Croatia recognizes the form of same-sex community in the form of life partnership, and even informal life partnership of persons of the same sex, the Decision of the CCRC No. UI-144/2019, of 29 January 2020, ${ }^{61}$ established the

57 Data obtained on the basis of an interview conducted on June 20, 2020 in two Registry Offices in Vukovar-Srijem and Osijek-Baranja counties

58 Lucić, N., Pravno uredenje braka i drugih oblika životnih zajednica, in: Rešetar, B. et al. (eds.), Suvremeno obiteljsko pravo i postupak, Pravni fakultet Osijek, Osijek, 2017, p. 61-102

59 Life Partnership of Persons of the Same Sex Act, op. cit., note 34, Article 73 (1)

60 Life Partnership of Persons of the Same Sex Act, op. cit., note 34, Article 73 (1)

${ }_{61}$ Decision and ruling of the Constitutional Court of the Republic of Croatia No. U-I-144/2019 and others of 29 January 2020, Available at: [https://www.hrt.hr/uploads/media/UI1442019dr.pdf], accessed 29. June 2020 
existence of discriminatory provisions, based on sexual orientation, in the Foster Care Act. ${ }^{62}$ The request for an assessment of the legality and compliance of the Foster Care Act with the Constitution Act was initiated by thirty-three members of the Croatian Parliament. The request was based on numerous rejections of foster care requests made by persons living in formal or informal life partnerships by the Ministry of Demography, Family, Youth and Social Policy of the Republic of Croatia. What was disputable in a particular case was that the Foster Care Act in defining a foster family omits to mention persons living in a same-sex life partnership, which according to the applicants constitutes a form of sexual orientation discrimination. According to the applicants, denials of foster care applications submitted by persons in same-sex life partnerships, also constitute a form of sexual orientation discrimination, especially as the rights of persons in same-sex life partnerships in Croatia are equal to those in marriage or cohabitation. In its decision, the CCRC emphasized that the exclusion of access of a certain social group to foster care services, without objective and well-argued reasons, reduces the potential of foster care as a public service given that the circle of persons who could meet the needs of its users is narrowed. Therefore, according to the CCRC, the Foster Care Act strives to achieve an important social legitimate goal - taking care of foster care users as a public service, and from the aspect of the constitutional principle of proportionality, its ability to achieve that goal is questioned. ${ }^{63}$ The CCRC provides that it is legitimate and necessary for foster parents to be subject to restrictions in order to protect the best interests of beneficiaries. However, CCRC points out that restrictions relating to the procedural aspect of foster care and apply only to one group of potential foster parents, determined solely by the form of family community in which they live, according to their sexual orientation, are not necessary in a democratic society, are discriminatory and therefore unacceptable according to Article 14 of the Constitution Act. CCRC also considers that such exclusion is, within the meaning of Article 16 of the Constitution Act, disproportionate in relation to the purpose of the prescribed restrictions. ${ }^{64}$ What is the result of the omission of same-sex partners, as possible foster parents from the Foster Care Act, can also be interpreted as the impossibility of fostering one's own relative. Precisely on this fact, the CCRC pointed out that the denial of adoption of one's own relative is also not necessary in a democratic society, declaring it discriminatory and unacceptable according to Article 14 of the Constitution

\footnotetext{
62 Foster Care Act, Official Gazette no. 115/18

63 Decision and Ruling of the Constitutional Court of the Republic of Croatia No. U-I-144/2019, op. cit., note 62, para. 24

64 Ibid., para. 25
} 
Act and disproportionate to the purpose of the prescribed restrictions. ${ }^{65}$ The life partnership in the field of the social welfare system creates the same effects that are recognized to the extramarital community by special regulations governing the social welfare system. ${ }^{66}$ The CCRC, therefore, pointed out that same-sex life partners in social need have a legitimate right to expect that in the case of foster care in the traditional type of foster care they can be placed together - based on the fact that the Life Partnership Act protects same-sex partnerships equally as well as cohabitation. ${ }^{67}$ The CCRC finds no reason for a different interpretation when it comes to the issue of the right to work, freedom of work and accessibility of every job to everyone under equal conditions, according to Article 54 of the Constitution Act, in the segment of professional foster care. According to the CCRC, Article 54 of the Constitution Act does not guarantee anyone employment and work in a particular job or position, but guarantees everyone under equal conditions access to an appropriate procedure, in which all applicants will be equally considered. ${ }^{68}$ The CCRC also points out that equal participation in all aspects of social life is guaranteed to same-sex communities in family life by the Constitution Act and the legislative anti-discrimination framework, which elaborates the constitutional value of gender equality under Article 3. Therefore, in the opinion of the CCRC, the Constitutional Order of Croatia, based on the stated constitutional values, respects the dignity of all minority social groups, guarantees them equal rights and prohibits discrimination in their exercise, which the competent bodies and courts must respect in interpreting and applying relevant legislation. ${ }^{69}$ Although the CCRC did not accept the applicant's request because it considers that his intervention cannot eliminate the discriminatory effects and the fact that the Foster Care Act has a legitimate aim that is not inconsistent with the Constitution Act, it has made great strides to protect same-sex communities in Croatia. However, CCRC stressed that all law enforcers must inevitably work in order to achieve the goal and purpose of the regulations. Which in this case means that the disputed legal provisions must be interpreted and applied in a way that will enable all persons on equal terms to participate in public foster care, regardless of whether the potential foster parent lives in marriage, cohabitation, or life partnership. This judgment is the first verdict in Croatia that opens numerous opportunities for same-sex partners. Such a judgment of the CCRC is revolutionary in Croatia

\footnotetext{
65 Ibid., para. 26

${ }_{66}$ Life Partnership of Persons of the Same Sex Act, op. cit., note 34, Article 64-65

67 Decision and Ruling of the Constitutional Court of the Republic of Croatia No. U-I-144/2019, op. cit., note 62 , para. 27

68 Ibid., para. 28

69 Ibid., para. $29(3)$
} 
and on the example of established discriminatory provisions in the Foster Care Act, ie establishing that omission of one social group constitutes discrimination, opens equal opportunity for all other legal regulations that do not mention life partnership and their rights.

\section{SOME OPEN ISSUES AND DE LEGE FERENDA GUIDELINES}

Regard to the increasing harmonization of national legislation with the acquis communautaire, numerous problems and open issues in the field of same-sex community, formal or informal, continue to arise. Hageanu states that judgment in the Comman case raises a number of other issues such as immigration, tax law, child protection law, as well as other issues related with rights of same sex partners. ${ }^{70}$ What Oprescu sees as an additional outstanding issue that the CJEU will certainly address in the future is the issue of recognizing same-sex marriage concluded in a non-EU country, with one partner being an EU citizen, as well as marriage between same-sex partners who have married in a MS of the EU and where child has been adopted. ${ }^{71}$ Valenti points out that the new approach of European supranational courts and the US Supreme Court is launching a meaningful dialogue between lower courts, state legislators and civil society in order to gradually achieve the full meaning of the principle of non-discrimination on the basis of sexual orientation. Therefore, it is possible to say that the current question is not whether same-sex marriage is constitutional, but who decides on that matter. ${ }^{72}$ What is certain is that the judgment in the Comman case paved the way for both, freedom of movement and many other fundamental rights that EU citizens enjoy. Therefore, the de lege ferenda, recognition of the legal effects of same-sex marriage and life partnerships needs to be harmonized in the form of a directive at EU level. ${ }^{73}$ In addition, changes need to be made as well to the definition of cohabitation at EU level because EU legislation does not distinguish between homosexual

70 Hageanu, op.cit., note 53, p. 154

71 See more: Oprescu, M. A., Notice de conjoint "in the Sens de la Directive 2004/38 du Parlement européen et du Conseil, du 29 April 2004, Synergies Roumanie, vol. 13, 2018, p. 131-142

72 See more: Valenti, V., Principles of Non-discrimination on the Grounds of Sexual Orientation and SameSex Marriage. A Comparison between the United States and the European Case Law, in: Pineschi, L. (ed.), General Principles of Law - The Role of the Judiciary, Springer International Publishing Swizerland, 2015, p. 215-242

73 The European Parliament adopted in 2010 a Resolution on aspects of civil law, commercial law, family law and private international law of the Stockholm Program Implementation Plan (2010/2080), the purpose of which is to recognize documents on the effects of citizenship in the EU. Such a resolution is certainly a good step towards achieving the ultimate goal, but it does not impose an obligation on Member States, and this document and EU case law could be a good basis for drafting a directive that would oblige Member States to exceed the current one to recognize the effects of civil status. 
and heterosexual cohabitation. As Lucić, Duić and Muhvić state, obstacles to the harmonization of national standards of legal protection of cohabitation are found where EU legislation should operate, in the national laws of the MS. ${ }^{74}$ The CJEU makes a number of decisions supplementing EU legislation, but only legislation regarding the distinction between heterosexual and homosexual extramarital unions would also greatly contribute to the strengthening of same-sex unions and their rights. It is necessary to adopt a directive that would address the issue of recognizing the impact of same-sex marriages and registered partnerships, even in those countries that do not know such a form of community in their legislation, which would also define the concept of informal heterosexual and homosexual communities. In addition, it is also necessary to insert the concept of life partners in all European directives concerning family rights, marital and extramarital partners. According to Rijpma and Koffeman, an approach based on mutual recognition of relations in the MS would allow for an inclusive definition of the family, while respecting the division of competences between the EU and its MS. ${ }^{75}$ From the judgment of the CJEU in the Maruko case to the judgment in the Coman case, and with the similar position of the ECtHR in the Oliari and Others $v$ Italy case, there are a number of adopted principles and protection of same-sex communities witch can use as a basis for the adoption of a directive aimed to harmonizing the procedures for recognizing same-sex marriages and registered partnerships in order to exercise the fundamental rights guaranteed by the EU and international law.

At the Croatian level, research conducted for the purposes of this paper has shown that there is no uniformity in Croatian legislation when it comes to mentioning the rights of persons living in formal or informal life partnerships. Thus, for example, the Social Welfare Act recognizes the term life partner, ie the term formal and informal life partner, and thus equates such a community with a marital or extramarital union. ${ }^{76}$ The Foster Care Act, therefore, does not recognize the concept of life partner and omits to regulate the issues of foster care by same-sex partners. The Family Act recognizes the concept of life partnership of persons of the same sex and elaborates their rights in its provisions, but in Article 1 (1), when the scope of that law is stated, it omits the application to formal and informal life partnership

\footnotetext{
74 See: Lucić, N.; Duić, D.; Muhvić, D., Izvanbračna zajednica: analiza međunarodnih i europskih normi u svrhu stvaranja nacionalnih standarda, Zbornik Pravnog fakulteta u Nišu, year LIX, no. 86, 2020

75 Rijpma, J.; Koffeman, N., Free Movement Rights for Same-Sex Couples Under EU Law: What Role to Play for the CJEU?, iIn: Gallo D.; Paladini L.; Pustorino P. (eds.) Same-Sex Couples before National, Supranational and International Jurisdictions. Springer, Berlin, Heidelberg, p. 455-491

76 Social Welfare Act, Official Gazette no. 130/17, Article 123 (a)
} 
of persons of the same sex. ${ }^{77}$ The Pension Insurance Act recognizes the concept of life partnership and provides for certain rights as well as for marital and extramarital partners. ${ }^{78}$ According to the Life Partnership of Persons of the Same Sex Act, referring to the provisions of the law governing inheritance, the life partner is equal to the spouse in inheritance, and children over whom he has partner care are equal to children born in a marital union. ${ }^{79}$ It is clear that this provisions provides protection with regard to the inheritance of life partner, but the Inheritance Act also does not recognize the concept of life partnership in its provisions ${ }^{80}$ Also, the Life Partnership of Persons of the Same Sex Act prescribes the same tax position in terms of privileges, exceptions and obligations, which is granted to spouses and their children, in accordance with a special law governing real estate tax, while the Real Estate Sales Tax Act, ${ }^{81}$ as well as the General Tax Act ${ }^{82}$ does not recognize the concept of life partnership. Nevertheless, if Croatian legislation recognizes all the rights of persons in same-sex communities on an equal footing with those enjoyed by spouses, it is necessary to introduce the term "formal and informal life partner" in order to ensure equality and non-discriminatory provision in all legislation related to marital and extramarital unions. Therefore, after the CCRC has determined that omission of a certain social group of persons in the provisions of the Foster Care Act is discriminatory, it is proposed to introduce the concept of formal and informal life partner in all Croatian legislative governing the rights and obligations of family, marital and extramarital unions, with the purpose of preventing discriminatory interpretation of the provisions of certain laws, and thus legal certainty.

\section{CONCLUSIONS}

In this paper, there was a discussion on sexual orientation discrimination in the EU. Following the international and European standards of protection against sexual orientation discrimination, a brief analysis of the current level of guaranteed rights of same-sex communities in EU MS is presented. After analyzing the practice of the CJEU, by which the EU has developed over time the increasing

\footnotetext{
77 Family Act, Official Gazette no. 103/15, 98/19, "This law regulates marriage, cohabitation of women and men, relations between parents and children, measures to protect the rights and welfare of the child, adoption, guardianship, alimony, compulsory counseling and family mediation, and procedures related to family relations and guardianship ", Article 1 (1)

78 Pension Insurance Act, Official Gazette no. 151/14, 33/15, Article 22 (a)

79 Life Partnership of Persons of the Same Sex Act, op. cit., note 34, Article 55

80 Inheritance Act, Official Gazette no. 48/03, 163/03, 35/05, 127/13, 33/15, 14/19

81 Real Estate Sales Tax Act, Official Gazette no. 115/16, 106/18

82 General Tax Act, Official Gazette no. 115/16, 106/18, 121/19, 32/20, 42/20
} 
protection of same-sex communities from sexual orientation discrimination, the impact of latest revolutionary judgment in the Comman case on changes to Romanian legislation was analyzed in the field of recognizing the impact of same-sex marriage concluded abroad. Judgments of the CJEU are binding MS and they should comply with them. An analysis of Romanian legislation has shown that Romania has not changed its legislation in the direction of the CJEU decision, refusing to do so, citing the fact that Romania does not recognize any form of same-sex communities and does not intend to change its legislation. Misinterpreting the CJEU judgment, Romania disregarded such a decision and refused to acknowledge the effect of a same-sex marriage concluded abroad. At the time of completion of this paper, the consequences for such deafness to the CJEU judgment by Romania, were absent. An analysis of Croatia's approach to recognizing the impact of same-sex marriages concluded abroad has established that Croatia is fully complying with CJEU decisions. Although Croatian legislation does not recognize the institute of same-sex marriage, every same-sex marriage concluded abroad by Croatian citizens is entered as a note on the life partnership of persons of the same sex in the Registry of Birth Certificates. Such recognition, although degraded into a life partnership in the Croatian system, has the effects of marriage and is equated with extramarital and marital unions, and life partners are guaranteed freedom of movement and the right of residence as a family member. However, based on the analysis of the judgment of the CCRC, it was established that the omission of one social group such as life partners from the Foster Care Act is a discriminatory provision and prevents life partners from fostering, even their own relatives. Although all rights of life partners are provided by the SameSex Life Partnership Act, the analysis shows inconsistency in Croatian legislation in emphasizing the rights of life partners. The omission of life partners from such legal provisions may lead to a discriminatory interpretation of such provisions, and it is proposed that, regardless of the provisions of the Same-Sex Life Partnership Act, life partners should be explicitly listed in all legal provisions relating to family rights, marital and extramarital partners in order to achieve legal certainty and equality. It is also proposed that a directive be adopted at EU level to recognize the effect of same-sex marriages or life partnerships in all MS for the realization of fundamental human rights and freedoms, regardless of whether a MS recognizes such or similar rights to same-sex communities. In addition, it is necessary to insert the concept of life partners in all others European directives concerning family rights, marital and extramarital partners. This would be a major step in protecting the fundamental human rights and freedoms to which every person is entitled, regardless of his or her marital, extramarital or partnership status. 


\section{REFERENCES}

\section{BOOKS, AND ARTICLES}

1. Andreescu V., From Legal Tolerance to Social Acceptance: Predictors of Heterosexism in Romania, Revista Romana de Sociologie, vol. 3-4, 201, pp. 209-231

2. Barić, S.; Vincan, S., Ustavnopravno načelo jednakosti i pravno uređenje istospolnih zajednica, Zbornik radova Pravnog fakulteta u Splitu, vol.. 50, no. 1, 2013, pp. 81-113

3. Borić, R., Pojmovnik rodne terminologije prema standardima Europske unije, Ured za ravnopravnost spolova Vlade RH, Centar za ženske studije, Biblioteka ONA, Zagreb, 2007

4. Hageanu, C., Articolul 277 din Codul civil român, încotro?, Revista Româană de Drept Privat, vol. 3, 2018, pp. 148-154

5. Jagielska, M., Eastern European Countries: From Penalisation to Cohabitation or Further? In Boele-Woelki, K.; Fuchs, A. (eds.) Legal Recognition of Same-Sex Relationships in Europe, National, CrossBorder and European Perspectives, Cambridge Portland, 2012, pp. 55-69

6. Joseph, S.; Castan, M., The International Covenant on Civil and Political, Rights: Cases, Materials and Commentary, 3rd edition, Oxford: Oxford University Press, 2013

7. Krešić, B., Zajednice života istog spola u pravu zemalja EU, Sarajevski otvoreni centar, Sarajevo, 2015

8. Lucić, N.; Duić, D.; Muhvić, D., Izvanbračna zajednica: analiza mectunarodnih i europskih normi u svrhu stvaranja nacionalnih standarda, Zbornik Pravnog fakulteta u Nišu, year LIX, no. 86, 2020, pp. 15-38

9. Lucić, N., Pravno uređenje braka i drugih oblika životnih zajednica, in: Rešetar B. et al. (eds.), Suvremeno obiteljsko pravo i postupak. Pravni fakultet Osijek, Osijek, 2017, pp. 61-102

10. Oprescu, M. A., Notice de conjoint "in the Sens de la Directive 2004/38 du Parlement européen et du Conseil, du 29 April 2004, Synergies Roumanie, vol. 13, 2018, pp. 131-142

11. Petrašević, T.; Duić, D.; Buljan, E., Prava istospolnih zajednica u Europskoj uniji s posebnim osvrtom na Republiku Hrvatsku, Strani Pravni život, vol. 61, no. 3, 2017, pp. 145-169

12. Rijpma, J.; Koffeman, N., Free Movement Rights for Same-Sex Couples Under EU Law: What Role to Play for the CJEU?, In: Gallo D.; Paladini L.; Pustorino P. (eds.) Same-Sex Couples before National, Supranational and International Jurisdictions. Springer, Berlin, Heidelberg, 2014, pp. 455-491

13. Szeibert-Erdős, O., Same-sex partners in Hungary - Cohabitation and registered partnerships, Utrecht Law Review, Igitur, vol. 4, no. 2, 2008, pp. 212-221

14. Tryfonidou1, A., The EU Top Court Rules that Married Same Sex Couples Can Move Freely Between EU Member States as "Spouses": Case C 673/16, Relu Adrian Coman, Robert Clabourn Hamilton, Asociaţia Accept v Inspectoratul General pentru Imigrări, Feminist Legal Studies, vol. 27, 2019, pp. 211-221

15. Valenti, V., Principles of Non-discrimination on the Grounds of Sexual Orientation and SameSex Marriage. A Comparison between the United States and the European Case Law, in: Pineschi, L. (ed.), General Principles of Law - The Role of the Judiciary, Springer International Publishing Swizerland, 2015, pp. 215-242 


\section{INTERNATIONAL AND EU LAW}

1. Charter of Fundamental Rights of the European Union [2012] SL C 326

2. Consolidated version of the Treaty on the Functioning of the European Union [2007] SL C 326

3. Council Directive 2000/78/EC establishing a general framework for equal treatment in employment

4. and occupation [2000] OJ L 303, Article 1

5. Council Directive 2003/86/EC on the Right to Family Reunification [2003] OJ L 251

6. Council Regulation (EU) 2016/1103 implementing enhanced cooperation in the area of jurisdiction, applicable law and the recognition and nforcement of decisions in matters of matrimonial property regimes [2016] SL L 183

7. Directive 2004/38/EC of the European Parliament and of the Council on the right of citizens of the Union and their family members to move and reside freely within the territory of the Member States amending Regulation (EEC) No 1612/68 and repealing Directives 64/221/EEC, 68/360/EEC, 72/194/EEC, 73/148/EEC, 75/34/EEC, 75/35/EEC, 90/364/ EEC, 90/365/EEC and 93/96/EEC [2004] SL L 158

8. European Convention for the Protection of Human Rights and Fundamental Freedoms, as amended by Protocols Nos. 11 and 14, 4 November 1950, ETS 5

9. International Covenant on Civil and Political Rights, 16 December 1966, TS 999

10. International Covenant on Economic, Social and Cultural Rights, 16 December 1966, TS 993, p. 3

11. Protocol 12 to the European Convention on Human Rights and Fundamental Freedoms on the Prohibition of Discrimination, 4 November 2000, ETS 177

12. Universal Declaration of Human Rights, 10 December 1948., 217 A (III)

\section{UNITED NATIONS}

1. Toonen v. Austria, No. 488/1992, United Nations, 1994

2. Xv. Colombia, No.1361 / 2005, United Nations, 2007

3. Young v. Australia, Communication No. 941/2000, United Nations, 2003

\section{COURT OF JUSTICE OF THE EUROPEAN UNION}

1. Case C-267/06 Tadao Maruko v Versorgungsanstalt der deutschen Bühnen [2008] ECLI 2008:179

2. Case C-267/12 Frédéric Hay v Crédit agricole mutuel de Charente-Maritime et des Deux-Sèvres [2013] ECLI 2013:823

3. Case C-673/16 Relu Adrian Coman, Robert Clabourn Hamilton and Asociatia Accept v Inspectoratul General pentru Imigrări, Ministerul Afacerilor Interne [2018] SL C 268

\section{ECHR}

1. Karner v. Austria (2003) 38 EHRR 528 
2. Oliari and Others $v$ Italy (2015) Application no. 18766/11 and 36030/11

3. Orlandi and others $v$. Italy (2017) 389 ECHR 1153

4. Salgueiro da Silva Mouta v. Portugal (1999) 31 EHRR 1055

5. Vallianatos and others $v$. Greece (2013) 59 EHRR 12

\section{LIST OF NATIONAL REGULATIONS, ACTS AND COURT DECISIONS}

1. Chech Civil Code [2012] 89/2012 Sb.

2. Constitution of the Republic of Croatia, consolidated text, Official Gazette No. 56/90, $135 / 97,08 / 98,113 / 00,124 / 00,28 / 01,41 / 01,55 / 01,76 / 10,85 / 10,05 / 14$, Article 62

3. Decisions of the Hungarian Constitutional Court, No. 20/1999 (VI. 25.), ABH, 1999, p. 159. and No. 37/2002 (IX. 4.), ABH, 2002

4. Dutch Civil Code [1992] NLD-1992-L-91671

5. Family Act, Official Gazette no. 103/15, 98/19

6. Foster Care Act, Official Gazette no. 115/18

7. General Tax Act, Official Gazette no. 115/16, 106/18, 121/19, 32/20, 42/20

8. Hungarian Civil Code, [1960] Act VI

9. Inheritance Act, Official Gazette no. 48/03, 163/03, 35/05, 127/13, 33/15, 14/19

10. Instruction for keeping Life Partnership Register, Official Gazette no. 147/2014

11. Ireland Marriage Act [2015] No. 35, previously Bill No. 78

12. Italian Act on civil partnerships between persons of the same sex, and on living together without being married, Official Gezette, No. 76

13. Life Partnership of Persons of the Same Sex Act, Official Gazette, No. 92/14, 98/19

14. Pension Insurance Act, Official Gazette no. 151/14, 33/15

15. Real Estate Sales Tax Act, Official Gazette no. 115/16, 106/18

16. Romania Code Civil, Officially Law No. 287/2009

17. Romanian Criminal Justice Act [2003] Official Gezette, no. 34, 378, 39, 42

18. Same-Sex Communities Act, Official Gazette, No. 116/2003

19. Social Welfare Act, Official Gazette no. 130/17

20. The Danish Registered Partnership Act [1989] D/341- H- ML, Act No. 372

\section{WEBSITE REFERENCES}

1. Decision and ruling of the Constitutional Court of the Republic of Croatia No. U-I144/2019 and others of 29 January 2020, Available at: [https://www.hrt.hr/uploads/media/ UI1442019dr.pdf], Accessed 29. June 2020

2. General Comment No. 18 of the Human Rights Committee, United Nations, 1989, para. 10, Available at: [http://www.bgcentar.org.rs/bgcentar/wp-content/uploads/2013/04/ Op\%C5\%A1ti-comments-Community-for-Human-Rights.pdf], accessed 10. April 2020 
3. Lipka, M.; Masci, D., Where Europe stands for gay marriage and civil unions, Pew Research Center, 2019, Available at: [https://www.pewresearch.org/fact-tank/2019/10/28/where-europe-stands-on-gay-marriage-and-civil-unions], accessed 10. April 2020

4. Pew Research Center, Eastern and Western Europeans Differ on Importance of Religion, Views of Minorities, and Key Social Issues, 2018, Available at: [https://fra.europa.eu/en/databases/ anti-muslim-hatred/node/4277], accessed 11. April 2020

5. Yogyakarta Principles - Principles on the application of international human rights law in relation to sexual orientation and gender identity, International Commission of Jurists (ICJ), 2007, Available at: [https://www.refworld.org/docid/48244e602.html], accessed 01. April 2020 